\title{
Factors Influencing Organizational Commitment of Employees in the Plantation Sector in Sri Lanka
}

\author{
Fernando, A.N.M., Wijesinghe, A.G.K.* and Abeynayake, N.R. \\ Department of Agribusiness Management, Faculty of Agriculture and Plantation Management, \\ Wayamba University of Sri Lanka, Makandura, Gonawila (NWP), 60170, Sri Lanka \\ *Corresponding Author: \\ Email: kusum_wijesinghe06@yahoo.com
}

\begin{abstract}
Organizational commitment refers to the individual's thoughts to stay in the organization and work effectively and positively for the organization. Organization commitment of employees is a key factor that contributes to the achievements of organizational goals. Final performance of an organization depends on the levels of commitment of its workers. This research focused to investigate the factors that influence on organizational commitment of employees in the plantation sector organizations of Sri Lanka. Affective commitment and normative commitment are the main two dependent variables for this study. A structured questionnaire survey was carried out to gather primary data from randomly selected 275 employees covering six organizations of the Tea, Rubber and Coconut sectors. Organizations were selected randomly. Data were analysed by using Confirmatory Factor Analysis (CFA) in AMOS in SPSS 21 version. The findings revealed that the nature of work, interpersonal relationship and work environment are the significant and positive factors that enhance affective commitment $(\mathrm{p}<0.001)$. Nature of work, work environment, and relationship between management and employees are the most significant and positive factors that enhance normative commitment $(\mathrm{p}<0.001)$ and pay and allowances significant at 0.01 probability on normative commitment. These findings will be helpful for all levels of managers, owners and policy makers to identify the main attributes that should be implemented in the organizations to enhance employee commitment.
\end{abstract}

KEYWORDS: Affective commitment, Normative commitment, Plantation sector employees

\section{Introduction}

Organizational commitment is an important factor, which is used to evaluate the performance of employees. The degree of organizational commitment of employees is highly considered as a principle component to achieve a successful performance in the organization. According to Colquitt et al. (2015), organizational commitment is a factor that shown how much an employee links himself to the organization, wish to spend in the organization and help to achieve organizational goals. Every organizations need fully committed employees because the world is rapidly changing with the technology and globalization that should be linked to the organization's competitive advantage. Therefore, only committed employees can forward their organization to the target objectives (Frankema et al., 2006). 
Final performance of an organization depends on the levels of commitment of its workers. Highly committed employees impact an organization to reach both its net profit margin and operating margin (Wijesinghe, 2018).

Tea, Rubber and Coconut are the main traditional plantation crops in Sri Lanka that brought many of the foreign exchange over the last several decades. Therefore, it is important to rethink to develop the plantation sector that plays a key role in the local economy. The foreign exchange earnings from the plantation sector were fluctuating in the past decades. According to the analysis of the Ministry of Plantation Industries, tea export earnings were only Rs. 231.7 billion in 2018 and in 2017, it was Rs. 233.3 billion. Rubber sector was the third largest export earner of Sri Lanka in 2018 that provided over 300000 job opportunities for employees. The export revenue of rubber products in 2018 was Rs. 147.39 billion and in 2017, it was Rs. 133.34 billion. In 2018, earnings from coconut exports were Rs. 94,722.62 billion in the country. Coconut plantation comprised 23445 hectares of lands under the cultivation in 2017, which accounts for approximately $12 \%$ of all agriculture lands in Sri Lanka (Progress Report-Ministry of Plantation Industries in Sri Lanka, 2018; Central Bank of Sri Lanka, 2018 and 2017).

Employee commitment is divided into three components i.e. affective commitment, continuance commitment and normative commitment (Lee and Kim, 2010; Gunly et al., 2009). In this study researchers only considered the affective commitment and normative commitment of employees. Affective commitment is an individual's emotions that cause to connect with the organization. According to researchers thoughts the individual is an attractive and responsible person who continues working in the company as a member (Meyer and Allen, 1991). Morrow (1993) has mentioned that the positive emotions of the employees towards their working organization can be defined as an affective organizational commitment (Singh and Gupta, 2015; Morrow, 1993). Individuals emotionally connect with their organizations to establish a firm identity based on values of an individual and the organization. Normative commitment is the sense of responsibility to continue working in the organization due to an individual's different socialization experiences that affect on employee commitment to the organization (Khan, 2013). This commitment type enhances the value of loyalty between the employee and the organization (Meyer and Herscovitch, 2001). The normative commitment describes the employee's belief about individual's responsibility to the organization. Individuals who are normatively committed to the organization remain because they strongly believe that it is the correct and moral behaviour to play. Normative commitment develops based on a collection of pressures from family, culture and during their socialization of new employees to the organization (Wiener, 1982).

The nature of work performed by employees has a significant impact on their level of organizational commitment. If employees satisfy from works, which are interesting and getting more opportunities can enhance their commitment to the organization. Employees should be matched with the job positions according to the variety of skills that the employees can utilize in their jobs to receive higher level of commitment (Wijesinghe, 2017; Luthans, 1998). Interpersonal relationship is one of the significant factors responsible for organizational commitment. 
Team works can improve the interpersonal relationships among employees and it is easy to present in the competitive world. Conflict management, clear communication skills, collaborating and listening are some of the main interpersonal skills that need to succeed in any organization (Bahrami et al., 2016).

Yamoah (2014) has mentioned that there was an impact of pay and allowances on employee organizational commitment and their job satisfaction. According to Sharma (2013), various components of compensation like basic salary, short term and long term incentives cause for motivation of employees. Pay levels and systems that are related with organizational performances, lead to create different employee behaviour outcomes. Bulut and Çulha (2010) found that facilitating training opportunities, training access and training support lead to enhance the organizational commitment of employees. Organization should be assured the correct time period and most suitable employees for training to promote employee commitment. Employees concern about the working environment of their organization, which includes job safety, pleasurable physical environment, flexible working hours, proper workload and affable staff. Improving work environment leads to create more committed employees towards their organization (Raziq and Maulabakhsha, 2015).

Tansel and Gazioglu (2012) suggested that, organization size plays an important role in managing employees' relationships. In large scale firms, it is difficult for managers to interact with all the employees. However, it is very essential to build strong relationships among every hierarchical layers inside the organization. According to Bahrami et al. (2016), top-level management should provide good guidance, support and maintaining good communication to build strong relationships between management and employees. Favourable relationships can achieve high level of organizational commitment.

Today, Sri Lanka is listed below in economic indicators when compared to the other developed nations in the world. Some of the reasons are low productivity of the organizations, increasing unemployment, government budgetary position and growing scarcity of resources. In this instance, plantation sector plays a considerable role in the economy of Sri Lanka. Therefore, the employees' performance of the plantation sector is a key component to Sri Lankan economy. If, employees have low commitment, it is an extra cost to the organization. Because it reduces organization's productivity that having employees misapply organization's resources thus contributes to extra cost (Fiorita et al., 2007).

Managers should be able to enhance employee commitment that contributes to increase organizational productivity while decreasing turnover. Because these are important to both employees and organization (Fiorita et al., 2007). Therefore, it is important to study this phenomenon in relation to the plantation sector employees in Sri Lanka to understand how employee commitment can be enhanced. In addition, there are no sufficient researches done in relation to employee commitment of the plantation sector organizations recently. Therefore, this study was focused to evaluate the factors that influence on employee commitment of the plantation sector organizations in Sri Lanka. 


\section{Methodology \\ Research Design}

The main objectives of this research study were to determine the impacts of the main six influential factors i.e. nature of work, interpersonal relationship, pay and allowances, employee training, work environment and relationship between management and employees on employee affective commitment and normative commitment in the plantation sector organizations in Sri Lanka. Reason behind the selection of the identified main six influential factors is the knowledge gathered from literature survey regarding the psychological aspects of employees' that contribute to employees' commitment (Yamoah, 2014; Sharma, 2013; Bulut and Çulha, 2010).

Therefore, the type of study is a quantitative study that generated statics through the survey data. This study explains the nature of a specific effect and explains the structural relationships between identified factors and employee affective and normative commitments. For the study, data were collected from the middle level employees in the plantation sector organizations in Sri Lanka. As the sampling technique, a nonproportionate stratified random sampling method was adopted to select the middle level employees consisting managers, supervisors, and management assistance. Data were collected from a sample of 275 respondents from six organizations representing tea, rubber and coconut sectors. From each sector, two organizations were selected randomly. Respondents were selected by using simple random sampling within the each employee category.

A structured questionnaire survey was conducted to gather primary data from the study population. The reason for using this questionnaire methodology was, to keep face confidentiality, to build credibility and to save official time of participants for the survey. Questionnaire was pre tested with a small sample of potential employees $(n=10)$ and minor modifications were done to the preliminary questionnaire. The questionnaire was consisted with the factors i.e. demographic factors, nature of work, inter personal relationship, pay and allowances, training, work environment, relationship between management and employee, affective commitment and normative commitment. Thirtyfour statements were used to asses these eight factors other than demographic factors. All these eight factors were assessed using a 5-point Likert type scale, ranging from 1 to 5 , where 1 was denoted "strongly disagree" and 5 was denoted "strongly agree". Table 1 shows the Likert Scale items that were used as indicators to capture employee perceptions towards the selected factors.

\section{Data Analysis}

Data were analysed by using the Structural Equation Modelling (SEM). Structural Equation Modelling is a set of numerical models that attempt to explain the relationships between multiple variables. For this purpose, the structure of the expressed interactions in a set of equations similar to a system of multiple reaction equations is examined. These equations reveal all the relationships between the factors (dependent and independent factors) involved in the analysis. As in factor analysis, constructions are unobservable (latent) factors that can be represented by multiple variables. 
Table 1: Description of the Likert Scale Items

\begin{tabular}{|c|c|c|}
\hline Factors & & Indicators \\
\hline \multirow{4}{*}{ Nature of Work } & NOW1 & (Job is interested for me) \\
\hline & NOW2 & (Gain of skills and knowledge from the job as expected) \\
\hline & NOW3 & (Able to maintain happy home life with the job) \\
\hline & NOW4 & (Dignity and respect from the job is as I thought) \\
\hline \multirow{4}{*}{$\begin{array}{l}\text { Inter Personal } \\
\text { Relationship }\end{array}$} & IPR1 & (Trust by superiors is as I expected) \\
\hline & IPR2 & (Cooperation among employees is as I expected) \\
\hline & IPR3 & (Free discussions with superiors as expected) \\
\hline & IPR4 & (Listening to employee's voice is excellent) \\
\hline \multirow{4}{*}{ Pay and Allowances } & PAA1 & (I am satisfied with the salary) \\
\hline & PAA2 & (I am happy on allowances given) \\
\hline & PAA3 & (I am satisfied on overtime payment system) \\
\hline & PAA4 & (Pay \& allowances system is very clear) \\
\hline \multirow{4}{*}{ Training } & TRA1 & (Training received at right time) \\
\hline & TRA2 & (Training programs are need based) \\
\hline & TRA3 & (Selection criteria for training are unbiased) \\
\hline & TRA4 & (Training programs given us are really beneficial) \\
\hline \multirow{4}{*}{ Work Environment } & WOE1 & (Pleasant work environment is available) \\
\hline & WOE2 & (Safety in work place assured) \\
\hline & WOE3 & (Sanitary facilities are well sufficient) \\
\hline & WOE4 & (Affable work environment with customers) \\
\hline \multirow{4}{*}{$\begin{array}{l}\text { Relationship } \\
\text { between } \\
\text { management \& } \\
\text { employees }\end{array}$} & RME1 & (HRM policies are communicated with us) \\
\hline & RME2 & (Employees participation in decision making is perfect) \\
\hline & RME3 & $\begin{array}{l}\text { (Communication network within the organization well } \\
\text { established) }\end{array}$ \\
\hline & RME4 & (Managers maintain good relation with workers) \\
\hline \multirow{5}{*}{$\begin{array}{l}\text { Affective } \\
\text { commitment }\end{array}$} & AFC1 & (I am willing to stay with the organization) \\
\hline & AFC2 & (I feel organization's problems are as mine) \\
\hline & AFC3 & (I am proud to talk about my organization with others) \\
\hline & AFC4 & (I have a strong sense for the organization) \\
\hline & AFC5 & (I feel my organization is as my family) \\
\hline \multirow{5}{*}{$\begin{array}{l}\text { Normative } \\
\text { Commitment }\end{array}$} & NOC1 & (Employee’s loyalty) \\
\hline & NOC2 & (Distraction to move another) \\
\hline & NOC3 & (I have a sense of moral obligation with this organization) \\
\hline & NOC4 & (I spend rest of my carrier with this organization) \\
\hline & NOC5 & (I feel this job Is the best job) \\
\hline
\end{tabular}


The main origins of SEM come from two familiar multivariate methods: factor analysis and multifunctional analysis. Thus, SEM can be considered a unique combination of these two methods. From this point of view, SEM can be considered as a technology for simultaneous estimation of relationships between measured and latent variables (measurement model), and relationships between the latent variables (structural model). SEM is a popular method of combining invisible factor analysis and regression analysis (simultaneous equation models) to demonstrate various relationships between invisible latent factors. In SEM, the variables can be external or endogenous and can apply to a group of interactions such as direct, indirect, multiple and inverse.

\section{Results and Discussion}

\section{Descriptive Statistics of the Sample}

Table 2 describes the demographic factors of respondents in the sample. In this study, there were $24 \%$ of respondents from tea sector, $40 \%$ from rubber sector and $36 \%$ from coconut sector.

\section{Table 2: Descriptive Statistics of the Sample}

\begin{tabular}{|c|c|c|}
\hline Parameter & Category & Percentage $(\%)$ \\
\hline Gender & $\begin{array}{l}\text { Female } \\
\text { Male }\end{array}$ & $\begin{array}{l}65 \\
35\end{array}$ \\
\hline Age & $\begin{array}{l}18-30 \text { years } \\
31-40 \text { years } \\
41-50 \text { years } \\
\text { Above } 50 \text { years }\end{array}$ & $\begin{array}{l}24 \\
33 \\
26 \\
17\end{array}$ \\
\hline Monthly Income & $\begin{array}{l}\text { LKR 10,000-20,000 } \\
\text { LKR 20,001-30,000 } \\
\text { LKR 30,001-40,000 } \\
\text { Above LKR 40,000 }\end{array}$ & $\begin{array}{c}5 \\
17 \\
39 \\
40\end{array}$ \\
\hline Marital Status & $\begin{array}{l}\text { Married } \\
\text { Unmarried } \\
\text { Divorced }\end{array}$ & $\begin{array}{c}71 \\
27 \\
2\end{array}$ \\
\hline Work Experience & $\begin{array}{l}\text { Less than } 5 \text { years } \\
5-10 \text { years } \\
10-15 \text { years } \\
\text { Above } 15 \text { years }\end{array}$ & $\begin{array}{l}27 \\
31 \\
17 \\
25\end{array}$ \\
\hline Educational Level & $\begin{array}{l}\text { Primary education from grade } 1 \text { to } 8 \\
\text { Secondary education of } \mathrm{O} / \mathrm{L} \text { and } \mathrm{A} / \mathrm{L} \\
\text { Diploma } \\
\text { Bachelor degree } \\
\text { Other }\end{array}$ & $\begin{array}{c}2 \\
39 \\
27 \\
24 \\
9\end{array}$ \\
\hline
\end{tabular}


Percentage of the female respondents $(65 \%)$ was greater than the male respondents $(35 \%)$ in the studied population. Sample was contained 33\% of the respondents in the category of $31-40$ years and $17 \%$ in above 50 years. Majority of the respondents (40\%) were in the category of more than LKR 40,000 of monthly income. Work experience of $5-10$ years represents by $31 \%$ of the population. Among the sample population, $39 \%$ had educated up to secondary education, $24 \%$ from bachelor degree and $2 \%$ only from primary education.

\section{Reliability Analysis of the Variables}

Cronbach's alpha was most common tool to measure reliability. Cronbach's alpha is acceptable when its value is greater than 0.7 (Hair et al., 1998). According to the analysis, all Cronbach's alpha values for the variables within 8 factors are greater than 0.7. Table 3 shows all the Cronbach's alpha values for each factor.

Table 3: Cronbach's Alpha for Each Factors

\begin{tabular}{lc}
\hline Factor & Cronbach's Alpha \\
\hline NOW (nature of work) & 0.79 \\
IPR (inter personal relationship) & 0.80 \\
PAA (pay and allowances) & 0.81 \\
TRA (training) & 0.76 \\
WOE (work environment) & 0.77 \\
RME (relationship between management and employees) & 0.82 \\
AFC (affective commitment) & 0.81 \\
NOC (normative commitment) & 0.77 \\
\hline
\end{tabular}

\section{Results of Model Fit Indices}

Model fit was assessed by using Multiple Fit Indices. Chi-square value (1955.917) for the model was statistically significant, Degrees of Freedom (DF) $=483$, Root Mean of Squared Error of Approximation (RMSEA) $=0.105$, Goodness-of-Fit Index (GFI) = 0.640 , Adjusted Goodness-of-Fit Index $(\mathrm{AGFI})=0.582$, Comparative Fit Index $(\mathrm{CFI})=$ 0.664. All these indicators gave adequate evidences for model fitting. Table 4 shows the results that obtained from Analysis of Moment Structure (AMOS).

\section{Results of Confirmatory Factor Analysis}

All thirty-four statements were used as indicators at the very first time for the analysis. However, the output showed that the model fit was insufficient to proceed with the same set of indicators. Therefore, it was pruned NOC1 indicator (employee's loyalty) which had low factor loading (below 0.05) and insignificant (at $\mathrm{p}=0.05$ ). That indicator was removed and re-estimated results mentioned below in Table 5 . 
Table 4: Measurement Model Fit Indices

\begin{tabular}{lc}
\hline Indices & Measurement Model Estimates \\
\hline Chi-square $\left(\chi^{2}\right)$ & 1955.92 \\
Degrees of Freedom (DF) & 483 \\
Probability Level & 0 \\
CFI & 0.66 \\
GFI & 0.64 \\
AGFI & 0.58 \\
RMSEA & 0.11 \\
\hline
\end{tabular}

Table 5: Confirmatory Factor Analysis Results

\begin{tabular}{|c|c|}
\hline Factor & Estimate \\
\hline NOW1 & 1.00 \\
\hline NOW2 & $1.21 * * *$ \\
\hline NOW3 & $0.80 * * *$ \\
\hline NOW4 & $1.10^{* * *}$ \\
\hline IPR1 & $0.83^{* * *}$ \\
\hline IPR2 & $0.67 * * *$ \\
\hline IPR3 & $0.96^{* * *}$ \\
\hline IPR4 & 1.00 \\
\hline PAA1 & $1.11 * * *$ \\
\hline PAA2 & $0.82 * * *$ \\
\hline PAA3 & $0.89 * * *$ \\
\hline PAA4 & 1.00 \\
\hline TRA1 & $0.99 * * *$ \\
\hline TRA2 & $0.55^{* * *}$ \\
\hline TRA3 & $0.10^{* * *}$ \\
\hline TRA4 & 1.00 \\
\hline WOE1 & $1.58^{* * *}$ \\
\hline WOE2 & $1.80^{* * *}$ \\
\hline WOE3 & $1.55^{* * *}$ \\
\hline WOE4 & 1.00 \\
\hline RME1 & 1.00 \\
\hline RME2 & $1.16^{* * *}$ \\
\hline RME3 & $0.79 * * *$ \\
\hline RME4 & $0.77 * * *$ \\
\hline AFC1 & 1.00 \\
\hline AFC2 & $0.87 * * *$ \\
\hline AFC3 & $1.05^{* * *}$ \\
\hline AFC4 & $0.95^{* * *}$ \\
\hline AFC5 & $0.92 * * *$ \\
\hline NOC2 & 1.00 \\
\hline NOC3 & $0.96^{* * *}$ \\
\hline NOC4 & $1.10^{* * *}$ \\
\hline NOC5 & $1.31 * * *$ \\
\hline
\end{tabular}

Note: Levels of statistical significance ***P<0.001, **P<0.01 
The CFA results show that standardized estimates are statistically significant except NOW1, IPR4, PAA4, TRA4, WOE4, RME1, AFC1 and NOC2 indicator variables.

NOW2 indicator shows the highest factor loading (1.211) towards the nature of work, and NOW2 indicates "gain of skills and knowledge from the job". The indicator of 'ability to discuss freely with superiors' (IPR3 indicator) highly reflects on the factor of interpersonal relationship (IPR) at 95.5\% level. PAA1 indicator shows the highest factor loading (1.114) towards the 'pay and allowances' that express the salary satisfaction of employees. Unbiased training selection (TRA3 indicator) makes the most influencing indicator (0.997) on training factor (TRA).

WOE2 indicator, which describes safety in the work place that highly reflects the factor of work environment (1.797). Employee participation for decision-making (RME2 indicator) shows the highest factor loading (1.155) towards the relationship between management and employee factor. AFC3 indicator shows the highest factor loading value that is 1.047 on affective commitment. AFC3 indicator describes an employee's perception as 'I am proud to talk about the organization with others'. NOC5 (I feel this job is the best for me) is the indicator that highly contributes to the factor 'normative commitment' of employees.

\section{Results of Standardized Regression Weights}

The findings reveal that nature of work (NOW), interpersonal relationship (IRP) and work environment (WOE) are the significant and positive factors that enhance affective commitment of the employees. Nature of work (NOW), pay and allowances (PAA), work environment (WOE) and relationship between management and employees (RME) are the significant and positive factors that enhance normative commitment of employees Table 6 shows Standardized Regression Weights for all the factors.

Table 6: Standardized Regression Weights

\begin{tabular}{lc}
\hline Hypothesized Relationship & Estimates \\
\hline Affective Commitment $\leftarrow$ Nature of Work & $0.22^{* * *}$ \\
Affective Commitment $\leftarrow$ Inter Personal Relationship & $0.18^{* * *}$ \\
Affective Commitment $\leftarrow$ Pay and Allowances & 0.08 \\
Affective Commitment $\leftarrow$ Training & -0.02 \\
Affective Commitment $\leftarrow$ Work Environment & $0.57^{* * *}$ \\
Affective Commitment $\leftarrow$ Relationship between M\&E & 0.06 \\
Normative Commitment $\leftarrow$ Nature of Work & $0.22^{* * *}$ \\
Normative Commitment $\leftarrow$ Inter Personal Relationship & 0.12 \\
Normative Commitment $\leftarrow$ Pay and Allowances & $0.17^{* *}$ \\
Normative Commitment $\leftarrow$ Training & -0.11 \\
Normative Commitment $\leftarrow$ Work Environment & $0.47^{* * *}$ \\
Normative Commitment $\leftarrow$ Relationship between M\&E & $0.19^{* * *}$ \\
\hline
\end{tabular}

Note: Levels of statistical significance $* * P<0.001, * * P<0.01$ 
Under the nature of work factor (NOW), four statements were included in which asked about 'job interest, skills and knowledge improvement by the job, ability to maintain happy home life with the job and dignity and respect received due to the job' from others. Factor of inter personal relationship (IPR) was consisted of 'trust on me by superiors, cooperation among employees, ability to free discussion with superiors and listening to employees' suggestions by superiors. Four statements were under the pay and allowances (PAA) i.e. 'salary satisfaction, pay and allowance system, over time payments and medical allowances'. Work environment is the highest affected factor on both affective and normative commitment. According to the analysis, the factor known as training does not significantly influence on employee commitment. Because the majority of the old employees think that training is only valuable for new employees. Some employees do not trust on the selection procedure for the training programs in the organization and as well as the usefulness of the trainings given (Bulut and Culha, 2010). However, effective training methods are essential in general to improve employee commitment to the organization.

\section{Structural Relationships}

Figure 1 illustrates the overall outcomes of the confirmatory factor analysis of Table 5 and Table 6.

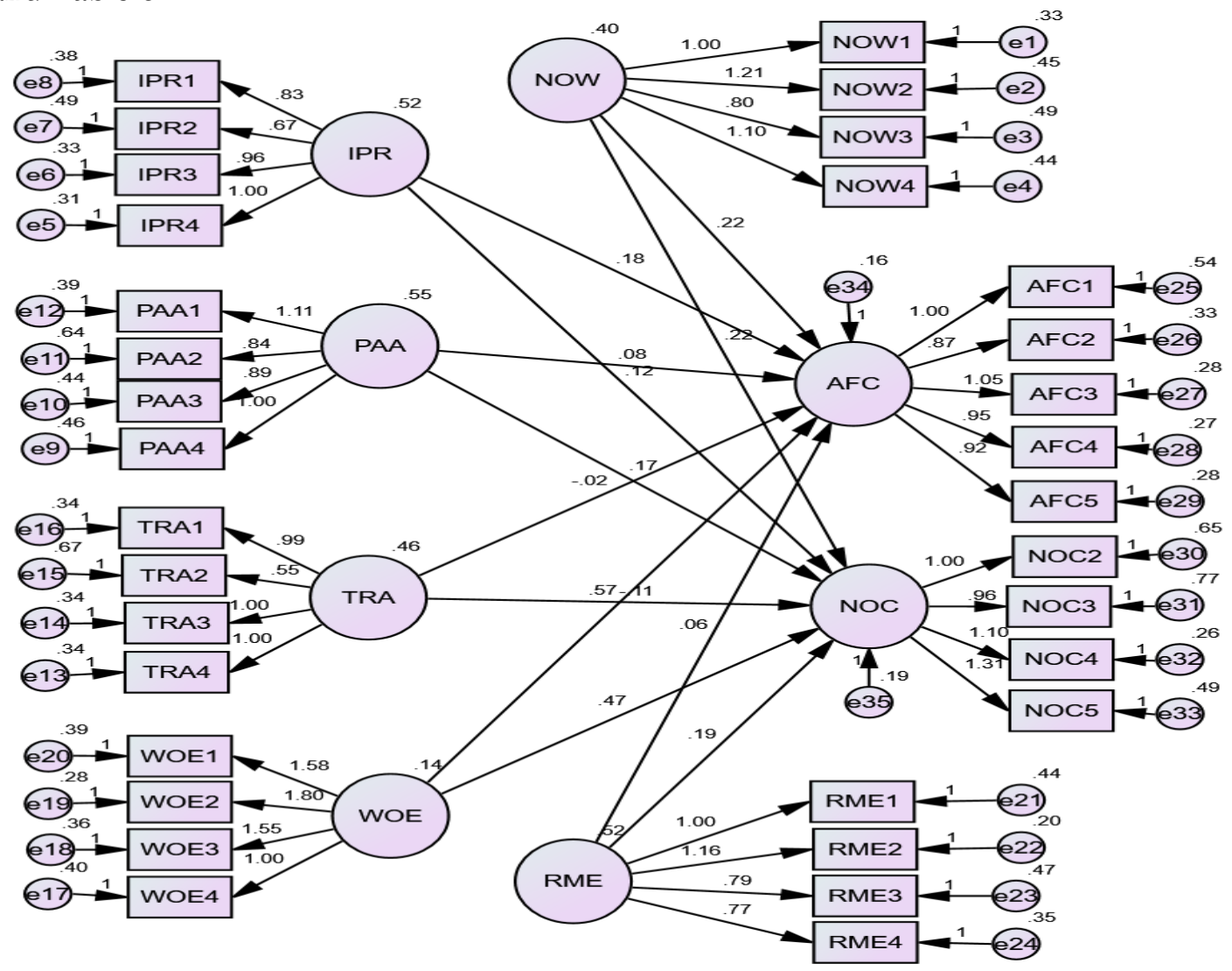

Figure 1: Structural Relationships between Variables 


\section{Conclusion and Policy Implications}

According to these results, researcher can conclude that nature of work (NOW), inter personal relationships (IRP) and work environment (WOE) are the significant and positive factors that can enhance affective commitment of employees in the plantation sector organizations. Nature of work (NOW), pay and allowances (PAA), work environment (WOE) and relationship between management and employees (RME) are the significant and positive factors that enhance normative commitment.

Therefore, management can implement relevant practices in which, creating and implementing factors that contribute to job interest of workers, supporting to maintain happy work-life balance, respecting employees, trust on workers, and creating cooperative and friendly workplace to enhance employees' affective and normative commitment to the organization. Other than that, managers can introduce: happy remuneration packages including allowances, opportunities for employee participation, effective communication network with employees, and providing opportunities to discuss matters of workers with the managers to enhance affective commitment. Superiors should listen to employees' suggestions where necessary. It will allow employees to feel as they are important to the organization. Further, administrative officers should take a heed to maintain safety, good sanitary facilities and a pleasurable work environment inside the organizations to make people feel to retain in the workplace.

These findings will be helpful for all levels of managers in the plantation sector organizations to identify the main factors that can enhance employee affective and normative commitment. Further studies are required to identify the other possible factors, which contribute to employee commitment in the plantation sector organizations in Sri Lanka.

\section{References}

Bahrami, M. A., Barati, O., Ghoroghchian, M.S., Montazer-alfaraj, R., and Ezzatabadi M.R. (2016). Role of Organizational Climate in Organizational Commitment: The Case of Teaching Hospitals. Osong Public Health and Research Perspectives, 7(2), 96-100. Bulut, C. and Culha, O. (2010). The Effects of Organizational Training on Organizational Commitment. International Journal of Training and Development, 14(4), 309-322.

Central Bank of Sri Lanka. (2018). Annual Report, Central Bank of Sri Lanka, Colombo. Central Bank of Sri Lanka. (2017). Annual Report, Central Bank of Sri Lanka, Colombo. Colquitt, J. A., Jeffery, A.L., \& Michael, J.W. (2015). Organizational behavior improving performance and commitment in the workplace. New York: McGraw Hill/Irwin.

Fiorita, J.A., Bozeman, D.P., Young, A., and Meurs, J.A. (2007). Organization Commitment, Human Resource Practices, and Organization Characteristic. Journal of Managerial Issues, 19(2), 186207.

Frankema, K.B., Rosendaal, B., and Taminiau, Y. (2006). Acting on frictions: learning blocks and flows in knowledge intensive organizations. Journal of European Industrial Training, 30(4), 291-309. 
Gunly, E., Aksarayli, M., and Percin, N.S. (2009). Job Satisfaction and Organizational Commitment of Hotel Managers in Turkey. International Journal of Contemporary Hospitality Management, 22(5), 693-717.

Hair, J.F., Anderson, R.E., Tatham, R.L. and Black, W.C. (1998). Multivariate Data Analysis, Fifth ed. New Jersey, Prentice Hall.

Khan, I. (2013). Determining the demographic impacts on the organizational commitment of academicians in the HEIs of DCs like Pakistan. European Journal of Sustainable Development, 2(4), 117-130.

Lee, K.Y. and Kim, S. (2010). The Effects of Commitment-Based Human Resource Management on Organizational Citizenship Behaviors: The Mediating Role of the Psychological Contract. World Journal of Management, 2 (1), 132-142.

Luthans, F. (1998). Organisational Behaviour. (8th ed). Boston: Irwin McGraw-Hill.

Meyer, J. P. and Allen, N. J. (1991). A Three-component Conceptualization of Organizational Commitment. Human Resource Management Review, 1, 61-89.

Meyer, J. and Herscovitch, L. (2001). Commitment in the workplace: toward a general model. Human Resource Management Review, 11(3), 299-326.

Morrow, P. C. (1993). The Theory and Measurement of Work Commitment.

Progress Report. (2018). Ministry of Plantation Industries, Colombo, Retrieved from < http://plantationindustries.gov.lk/web/images/pdf/2019/Progress_report_20 18_English.pdf>.

Raziq, A. and Maulabakhsh, R. (2015). Impact of Working Environment on Job Satisfaction. Procedia Economics and Finance, 23, 717-725.

Sharma, R. (2013). The Impact of various components of Compensation on the Motivation level of employees - A comparative study of selected Indian Public and Private sector Banks. International Journal of Application or Innovation in Engineering \& Management, 2(7), 511-516.

Singh, A. and Gupta, B. (2015). Job involvement, organizational commitment, professional commitment, and team commitment. Benchmarking an International Journal, 22(6), 1192-1211. Available at <https://doi.org/10.1108/BIJ-01-20140007>.

Tansel, A. and Gazioglu, S. (2012). Management-Employee Relations, Firm Size and Job Satisfaction. Economic Research Center ERC Working Papers in Economics $12 / 11$.

Wiener, Y. (1982). Commitment in organizations: A normative view. Academy of Management Review, 7(3), 418-428.

Wijesinghe, A.G.K. (2018). Interaction between human-oriented leader behavior and person-organization value fit on employee performance. Asian Journal of Management Science \& Education, 7(3).

Wijesinghe, A.G.K. (2017). An Exploratory Examination of Interactions between Leadership Behavior and Person-Organization Value Fit on Employee Performance, Kelaniya Journal of Management, Vol. 06 (02) Page 15.

Yamoah, E. E. (2014). Exploratory Analysis of Compensation and Employee Job Satisfaction. Developing Country Studies, 4(12), 27-35. 